\title{
Adventitious rooting of conifers: influence of physical and chemical factors
}

\author{
Carla Ragonezi $\cdot$ Krystyna Klimaszewska • \\ Mário Rui Castro • Mónica Lima • Paulo de Oliveira • \\ Maria Amely Zavattieri
}

Received: 23 December 2009/Revised: 22 July 2010/Accepted: 18 August 2010/Published online: 9 September 2010

(C) Springer-Verlag 2010

\begin{abstract}
In conifers, vegetative propagation of superior genotypes is the most direct means for making large genetic gains, because it allows a large proportion of genetic diversity to be captured in a single cycle of selection. There are two aims of vegetative propagation, namely large-scale multiplication of select genotypes and production of large numbers of plants from scarce and costly seed that originates from controlled seed orchard pollinations. This can be achieved, in some species, either through rooted cuttings or rooted microshoots, the latter regenerated through tissue culture in vitro. Thus far, both strategies have been used but often achieved limited success mainly because of difficult and inefficient rooting process. In this overview of technology, we focus on the progress in defining the physical and chemical factors that help the conifer cuttings and microshoots to develop adventitious roots. These factors include plant growth regulators, carbohydrates, light quality, temperature and rooting substrates/media as major variables for
\end{abstract}

Communicated by M. Buckeridge.

C. Ragonezi · M. R. Castro - M. Lima - M. A. Zavattieri ( $\square)$

Laboratory of Breeding and Plant Biotechnology,

Institute of Mediterranean Agricultural Sciences,

University of Évora, 7002-554 Évora, Portugal

e-mail: zavattieri@uevora.pt

K. Klimaszewska

Natural Resources Canada, Canadian Forest Service,

Laurentian Forestry Centre, 1055 du PEPS, P.O. Box 10380, Stn.

Sainte-Foy, Québec, QC G1V 4C7, Canada

P. de Oliveira

Laboratory of Soil Microbiology,

Institute of Mediterranean Agricultural Sciences,

University of Évora, 7002-554 Évora, Portugal development of reliable adventitious rooting protocols for different conifer species.

Keywords Cuttings - Gymnosperms - In vitro culture · Micropropagation $\cdot$ Microshoots

$\begin{array}{ll}\text { Abbreviations } & \\ \text { ACC } & \text { 1-Aminocyclopropane-1-carboxylic acid } \\ \text { AOA } & \text { Aminooxyacetic acid } \\ \text { ARF } & \text { Adventitious root formation } \\ \text { AVG } & \text { Aminoethoxyvinylglycine } \\ \text { BA } & \text { 6-Benzyladenine } \\ \text { cGMP } & \text { Cyclic guanosine monophosphate } \\ \text { CW } & \text { Cool white light } \\ \text { DCR } & \text { Gupta and Durzan (1985) } \\ \text { GA } & \text { Gibberellic acid } \\ \text { GD medium } & \text { Gresshoff and Doy (1972) } \\ \text { GL } & \text { Growth-lux } \\ \text { IAA } & \text { Indole-3-acetic acid } \\ \text { IBA } & \text { Indole-3-butyric acid } \\ \text { L9 medium } & \text { Ewald (2007b) } \\ \text { LP medium } & \text { Quorin and Lepoivre (1977) } \\ \text { MAPK } & \text { Mitogen-activated protein kinase } \\ \text { MS medium } & \text { Murashige and Skoog (1962) } \\ \text { NAA } & \text { Naphthalene acetic acid } \\ \text { PGR } & \text { Plant growth regulator } \\ \text { PPFD } & \text { Photosynthetic photon flux densities } \\ \text { PS medium } & \text { Pinus strobus medium-Tang and Newton } \\ & \text { (2005a) } \\ \text { PBZ } & \text { Paclobutrazol } \\ \text { RD } & \text { Red-rich daylight } \\ \text { RIM medium } & \text { Abo El-Nil (1982) } \\ \text { RW medium } & \text { Risser and White (1964) } \\ \text { SH medium } & \text { Schenk and Hildebrandt (1972) } \\ & \end{array}$




$\begin{array}{ll}\text { STS } & \text { Silverthiosulfate } \\ \text { TE medium } & \text { Tang et al. (1998) } \\ \text { TDZ } & \text { Thidiazuron } \\ \text { WPM medium } & \text { Lloyd and McCown (1981) } \\ \text { WW } & \text { Warm white }\end{array}$

\section{Introduction}

Vegetative propagation of trees has been a useful tool in traditional tree improvement and holds important prospects for reforestation (Libby 1986). It provides the possibility for multiplication of select superior trees with favorable genetic combination and to produce genetically homogenous plant material that will grow predictably and uniformly. In addition, improved efficiency in management and finished product utilization may also be achieved (Sutton 2002).

Conifers (cone-bearing trees) are the best known and most important economically among gymnosperms, covering approximately $60 \%$ of the forested areas of the world, and are mostly used for the production of softwood lumber, pulp and paper (Wenger 1984). Conifers comprise eight families, 68 genera and 629 species (Farjon 1998) including pines (Pinus spp.), spruces (Picea spp.), cowtail pine (Cephalotaxus spp.), cypress pine (Callitris spp.), firs (Abies spp.), larches (Larix spp.), bald cypresses (Taxodium spp.), yellowwood (Podocarpus spp.), yews (Taxus spp.), arbor vitae (Thuja spp.) and junipers (Juniperus spp.) (Farjon 1998).

In spite of the major role conifers are bound to play in reforestation strategies, current research on their vegetative propagation is not sufficiently developed (Sutton 2002). In part, this is due to the slow progress in propagation methods, mainly because of rooting problems associated with the tree maturation phase, an age-related developmental process that affects reproductive competence, morphology, and growth rate (Greenwood and Hutchison 1993).This notwithstanding, commercial scale propagation through rooted cuttings of young trees has been reported for radiata pine (Pinus radiata D. Don.), Norway spruce (Picea abies [L.] Karst.), Sitka spruce (Picea sitchensis [Bong.] Carr.), black spruce (Picea mariana [Mill.] B.S.P.) and sugi (Cryptomeria japonica D. Don) (Menzies et al. 2001). For a few economically important forest conifer species, an alternative vegetative, large-scale in vitro propagation technology has been developed, called somatic embryogenesis that utilizes mature or immature seed embryos as starting explants (reviewed by Klimaszewska et al. 2007). The advantages of somatic embryogenesis over rooted cuttings are: unlimited number of clonal somatic plants that can be produced from a single seed embryo (without a need for a separate step involving adventitious rooting) and the possibility of long-term storage of a given genotype in liquid nitrogen (cryopreservation). For example, in Norway spruce, both means of vegetative propagation, namely somatic embryogenesis and rooted cuttings of donor somatic trees, are being combined for clonal selection and commercial production of genetically superior seed families (Lamhamedi and Tousignant 2008).

Adventitious roots are post-embryonic roots that arise from the stem and leaves and from non-pericycle tissues in old roots. These roots may form naturally from stem tissue or may be induced by stressful environmental conditions, by mechanical damage or following tissue culture regeneration of shoots ( $\mathrm{Li}$ et al. 2009). Adventitious root formation (ARF) is a critical step in vegetative propagation. An efficient rooting treatment can lead to a high percentage of rooting and a higher quality of the root system (De Klerk et al. 1997). Quality involves root number and length, and the absence of callus at the base of a shoot, all of which influence the performance of the plants after transfer to soil (Mohammed and Vidaver 1990). Many factors, during the rooting phases, can cause poor quality of the shoots at the time of planting, thus affecting growth (De Klerk et al. 1999; Hartmann et al. 2002; Mohammed and Vidaver 1990).

Adventitious rooting is a complex developmental process that consists of three successive but interdependent physiological phases: induction, initiation and expression, and each of these phases have different requirements. The induction phase comprises molecular and biochemical events without visible changes. The initiation phase is characterized by cell divisions and root primordia organization. The expression phase is characterized by intra-stem growth of root primordia and root emergence ( $\mathrm{Li}$ et al. 2009). The chemical and physical factors that affect rooting include plant growth regulators (PGRs) (Wiesman et al. 1989; Davis and Haissig 1990), nutrients (the carbohydrate source foremost) (Wiesman and Lavee 1995), temperature and light (Haissig 1990; Corrêa and Fett-Neto 2004). Increasing body of knowledge on ARF pathway activation is generated from research on angiosperms. Recently, it has been discovered that nitrate, both a nitrogen source and a signal molecule, is transported by the NRT1.1 nitrate transporter and the transduction of nitrate signal is associated with a modification of auxin transport (Krouk et al. 2010). Thus, the NRT1.1 represses lateral root growth in Arabidopsis at low nitrate concentration by promoting auxin transport out of these roots. In mung bean, the adventitious root induction phase was regulated by a complex set of cellular messengers, among which some were activated by hydrogen peroxide, nitric oxide and 
calcium (Li and Xue 2010). However, the signaling network responsible for root development has not been discovered yet.

In tissue culture, plant regeneration can be achieved either through the development of axillary shoot buds or through adventitious shoot formation, most frequently from callus. In both cases, the microshoots have to be rooted through adventitious rooting. The process of in vitro organ regeneration from the explants occurs through an apparent reversal of cell differentiation and acquisition of meristematic characteristics (Gahan 2007). Because many environmental and endogenous factors regulate rooting, some aspects of this regulation can be exploited to control rooting in vitro, through the application of chemicals, light and/or temperature control, or biotization. Different types of chemicals may be applied: PGRs to promote cell dedifferentiation, trigger the initial meristematic activity (Wiesman et al. 1989; Davis and Haissig 1990) and to promote the elongation and development of formed roots (Hartmann et al. 2002; Wiesman et al. 1989); nutrients to promote growth of the new roots (Wiesman and Lavee 1995); and protecting agents, such as biocides, to help protect against pathogens during the entire rooting period if carried out in a non-sterile substrate (Henrique et al. 2006).

Adventitious rooting in conifers has long been discussed, but the available information is fragmentary and circumstantial. Since the extensive articles by Gaspar and Coumans (1987) and Mohammed and Vidaver (1988) appeared over 20 years ago, no other review on root production and plantlet development in conifers has been published. Some aspects, widely discussed in those reviews, such as biological factors, root morphogenesis, genetic stability and acclimatization, are not covered in the present review. Instead, we focused on the progress in defining the chemical and physical factors that help the conifer cuttings and in vitro regenerated microshoots to develop adventitious roots. We compiled (mostly in the tabular form) the most successful, for a given conifer species, protocol/s of chemical treatments and physical factors that promoted adventitious rooting in both propagation systems.

\section{Rooting of conifer cuttings}

Four discrete stages of adventitious root formation in cuttings can be distinguished (Hamann 1998): (1) proliferation of cells at the base of the cutting, (2) differentiation of wound vascular tissue and periderm, (3) dedifferentiation of a zone near the wound cambium and wound phloem to form a root initial, and (4) formation of a root meristem. To obtain high-quality young plants in the shortest possible time, cuttings must root quickly and abundantly. Cuttings must also be able to produce lateral branching and grow fast after rooting (Moe and Andersen 1988). Propagation by cuttings has long been established in many conifer species. Ritchie (1991) calculated that more than 65 million rooted conifer cuttings were already produced around the world, and that half of this production was for sugi (C. japonica) in Japan, at least 10 million for radiata pine $(P$. radiata) in Australia and New Zealand, and about 21 million for Norway spruce ( $P$. abies), Sitka spruce $(P$. sitchensis) and black spruce ( $P$. mariana) in Canada, Scandinavia and the British Isles together.

In conifers, in addition to chemical and physical rooting treatments, the success of propagation by cuttings depends on a variety of other factors that include cutting collection time and season, cutting size, whether the needles are kept or not, condition and age of the source plant, plant nutritional condition, pruning treatments, and type and health of the cuttings at collection (Silva 1985). The role of donor plant growing conditions has long been recognized as important in influencing the rooting capacity of cuttings (Hartmann and Kester 1983; Moe and Andersen 1988).

Plant growth regulators

\section{Auxins}

For many decades, IBA has been applied to different plant species to induce adventitious roots, and conifers follow the rule. Nordström et al. (1991) attributed this preference, relative to IAA, to the higher stability of IBA. On the other hand, in many conifers the cuttings respond well to a pulse treatment with NAA. The combinations of various types of PGRs, the concentrations and application are extensive and are summarized in Table 1. Although IBA promoted rooting of cuttings in most of the conifers, in Pinus spp. NAA was also used at concentrations that varied between 1.6 and $2.7 \mathrm{mM}$. IBA was most frequently used at 24.6 or $49 \mu \mathrm{M}$ mixed with talc or in water solution, and usually involved a quick dip or pulse treatment of the cut surfaces, with or without additional wounding, and was followed by transfer of the cuttings to substrates or to water nutrient solutions for rooting. In most cases, mixtures of sand, perlite and/or vermiculite were used in the substrates without any particular preference. The highest mean rooting percentage obtained in various experiments was $86 \%$ (Table 1).

\section{Polyamines}

Polyamines are generally considered to be growth regulators that are implicated in a range of developmental processes (Martin-Tanguy 2001; Kaur-Sawhney et al. 2003; Couée et al. 2004). It has been reported that the inhibition 


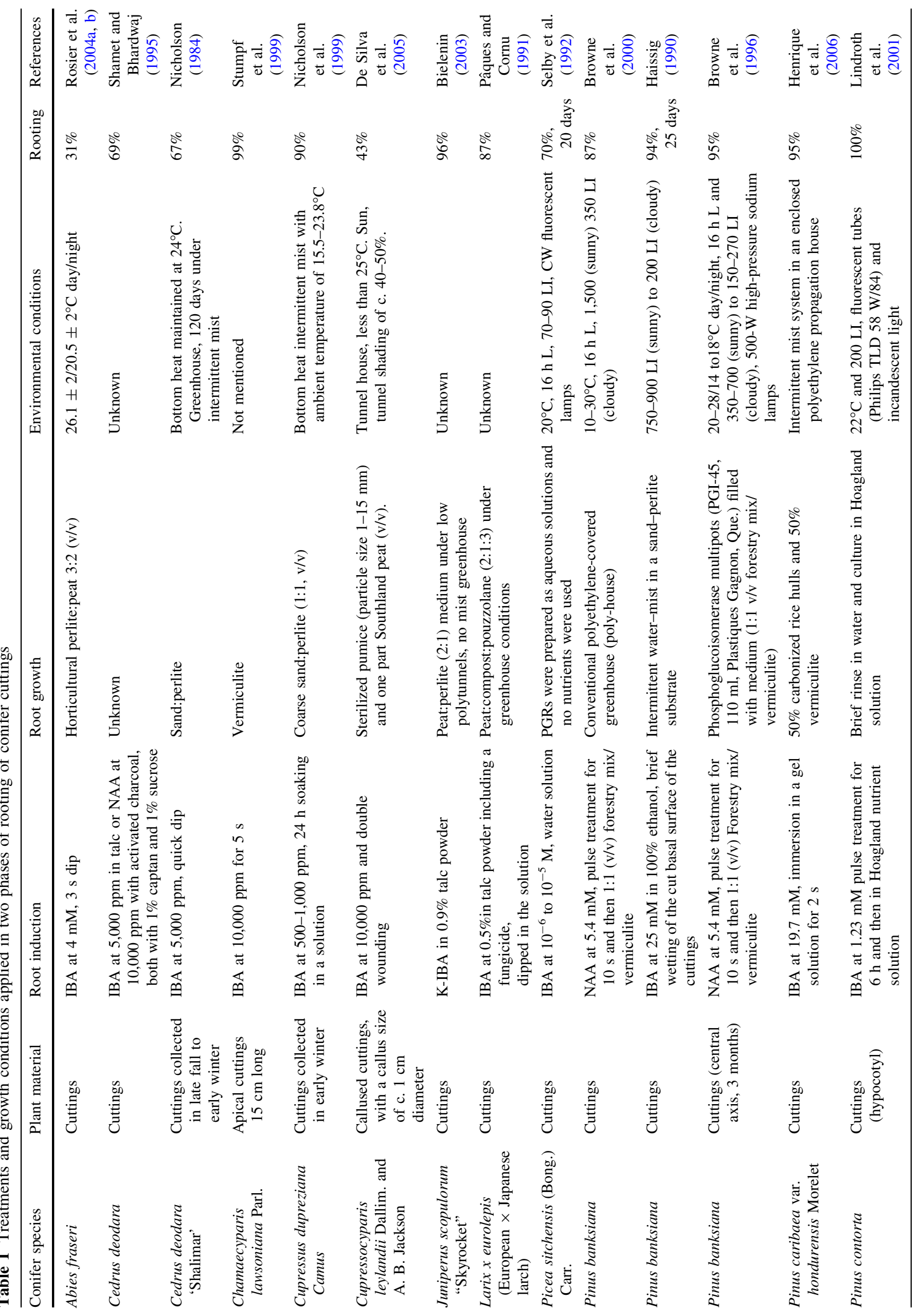




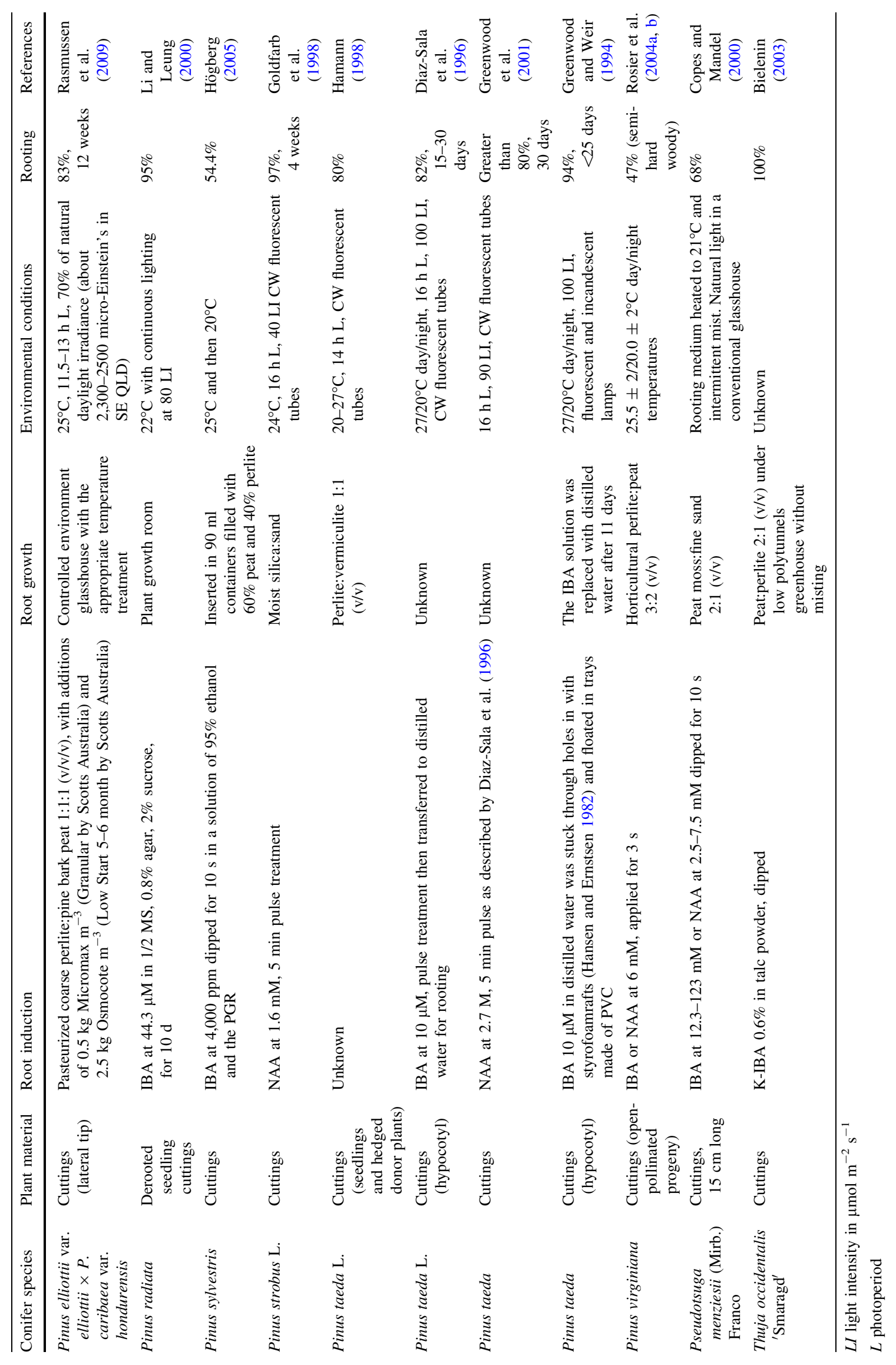


of polyamine synthesis blocks the mitotic cell cycle by blocking the transition between $\mathrm{G} 1$ and $\mathrm{S}$ phase where increased levels of spermidine and spermine have been found (Couée et al. 2004). Both Martin-Tanguy and Carré (1993) and Tarenghi et al. (1995) hypothesized that the endogenous concentrations of polyamines might be growth limiting based on observations of the developmental stimulation of higher plants. A direct relationship between high polyamine content, such as putrescine and spermine, and the onset of ARF has been demonstrated, which accentuates the possible participation of these substances in the general cellular processes of division and differentiation in the rooting process (Couée et al. 2004; MartinezPastur et al. 2007). Polyamine metabolism has also been pointed as responsive to environmental circumstances, therefore playing an important role in the relations between plant and external conditions (Couée et al. 2004; Tang and Newton 2005b).

Tang and Newton (2005b) tested the influence of polyamines on the overall rooting frequency of Pinus virginiana. In their trials, the administration of $0.001 \mathrm{mM}$ putrecine or spermidine in the NAA supplemented medium resulted in a $25 \%$ increase of rooting frequency, whereas $0.001 \mathrm{mM}$ spermine caused a $6.7 \%$ decrease of rooting frequency.

\section{Ethylene}

The information concerning ARF in cuttings of conifers and ethylene is limited to a few articles. In general, Ethrel (a commercial formulation of the slow-release ethylene compound ethephon) promoted rooting and root growth in Engelmann spruce 2 weeks after planting (Scagel and Linderman 2000). Ethrel induced changes in root initiation of cuttings of Douglas fir [Pseudotsuga menziesii (Mirb.) Franco] 2 weeks after application and these changes were positively correlated with subsequent increases in shoot growth. In these studies, the results indicated that exogenously applied Ethrel influenced root initiation indirectly by increasing levels of free IAA at the rooting site (Scagel et al. 2000). Ethrel was also reported to increase IAA conjugates in roots of Engelmann spruce (Picea engelmannii Parry ex Engelm.), lodgepole pine (Pinus contorta Dougl.) and Douglas fir. On the other hand, Bollmark and Eliasson (1990) concluded that the enhanced rooting of Norway spruce ( $P$. abies) hypocotyl cuttings, promoted by the treatment with ACC or Ethrel, was attributed to the ethylene-mediated acceleration of the breakdown of cytokinins.

When cuttings of Japanese black pine (Pinus thunbergii Parl.) were soaked for $10 \mathrm{~min}$ in Ethrel solution $(69.2 \mu \mathrm{M}$ ethephon) $24 \mathrm{~h}$ prior to soaking in Oxyberon $(19.7 \mathrm{mM}$ IBA solution), a significantly higher rooting ability was observed compared with the controls without the pretreatment with Ethrel (Mori, Miyahara, Tsutisumi, Kondo, unpublished). Similarly in P. abies L. (Karst), the hypocotyl cuttings produced 64 adventitious roots after 28-days treatment with $0.1 \mu \mathrm{M}$ Ethephon compared with 22 roots in untreated controls and with two roots after treatment with the ethylene inhibitor $\mathrm{CoCl}_{2}$ at $10 \mu \mathrm{M}$ (Wang and Pan 2006).

\section{Ethylene inhibitors}

Several ethylene inhibitors, compiled by Kumar et al. (1998), inhibit both ethylene biosynthesis or ethylene actions in a plant. Among the most commonly used are aminoethoxyvinylglycine (AVG) and aminooxyacetic acid (AOA), both inhibiting 1-aminocyclopropane-1-carboxylic acid (ACC) synthase and cobalt ions that inhibit the conversion of ACC to ethylene (Biddington 1992). Another inhibitor widely used is the silver ion, either as nitrate or as more mobile thiosulphate (STS), which excels in ethylene action inhibition (Beyer 1976). Inhibition of ethylene may lead to a lower number of adventitious roots, decrease of response to endogenous and exogenous auxins and reduced root hair formation (Clark et al. 1999). Ethylene itself has been reported to have no effect or even inhibit rooting depending on its concentration and genotypes, and therefore its role is still disputed (Mudge 1988). Inhibitors, when at high concentrations can promote stress, resulting in the synthesis of ethylene and root formation, thus defeating the purpose of their use. De Klerk et al. (1999) reported that STS may induce ethylene formation because silver is a heavy metal and damages the tissue. When STS was added along with auxins, the appearance of the rooted microcuttings at the time of transplanting was strongly improved (De Klerk et al. 1999).

As described by Kumar et al. (1998), ethylene inhibitors work within specific concentrations. The use of these substances under or above the recommended levels, might not have an inhibiting effect as desirable, or might promote the ethylene synthesis due to tissue damage (De Klerk et al. 1999). Also, there is not much work relating conifers with ethylene inhibiting substances, since the actual major scientific goal is to promote and improve conifer rooting and not the opposite. Nonetheless, such a study is fundamental to fully comprehend the role of ethylene in conifer ARF.

\section{Plant growth retardants}

Plant growth retardants are organic compounds that retard cell division and cell elongation (Arteca 1995). A number of growth retardants and inhibitors have been tested for their ability to influence rooting of cuttings. They are responsible for antagonizing the activity or inhibiting the 
synthesis of gibberellins, which normally inhibit rooting (Hartmann and Kester 1983; Davis et al. 1988).

Henrique et al. (2006) investigated the effect of different levels of auxins (NAA, IBA) and gibberellin synthesis inhibitor (PBZ) on the rooting of $4-6 \mathrm{~cm}$ long shoots obtained from cuttings of Pinus caribaea var. hondurensis Morelet. Sixty days after planting, the IBA-treated cuttings rooted at a higher frequency than those treated with NAA, but IBA applied together with PBZ was the most effective treatment. However, daminozide (currently used as a growth retardant for many plants) inhibited rooting of Chamaecyparis obutusa seedling cuttings after spray application of 2,000 ppm wettable solution (Shigehiro 2006).

\section{Carbohydrates}

Non-structural carbohydrates usually accumulate in needle fascicles during propagation, sometimes after an initial decrease. However, concentrations of specific carbohydrates such as sucrose or glucose in needle fascicles may not be uniform among tissues or with time during propagation (Veierskov 1988). Perhaps, the changing concentrations of specific carbohydrates in cuttings during propagation are linked to the direct control of ARF, for instance, because auxin treatments often concomitantly promote adventitious rooting and modify concentrations of individual carbohydrates within specific regions of cuttings during propagation (Haissig 1990).

Nevertheless, in a study with Sitka spruce cuttings, little correlation between rooting and concentration of sugars in stems and foliage was found (Van den Driessche 1983). It is possible that interaction between carbohydrates and hormones, nitrogen and carbon ratios, light and carbohydrate and also temperature pre-treatments, as well as the carbohydrates status of the mother plants, make the comparison of results from different studies difficult.

\section{Light}

Roots of $P$. radiata cuttings from seedlings had the highest dry weight under high PPFD, which had a red to far-red ratio similar to daylight (Wenger 1984). In other experiments with $P$. radiata, the best rooting conditions for short shoots were: treatment with $50 \mathrm{ppm}$ IBA for $24 \mathrm{~h}$, then planting at $20-25^{\circ} \mathrm{C}$ under a 12 -h photoperiod (as compared to 18 -h photoperiod or continuous illumination). The needle fascicles rooted better if they were collected during winter or early spring, suggesting a direct influence of short days (Kummerow 1966).

Both McClelland et al. (1990) and Corrêa et al. (2005) have stressed the need for increased efficiency of the process and that rooting should be carried out in the dark for the first few days. However, rooting can be influenced by light intensities, as reported by Kunneman and Ruesink (1997) who showed better responses to $66-83 \mu \mathrm{mol} \mathrm{s}{ }^{-1}$ $\mathrm{m}^{-2}$ in a few Juniperus cultivars, while $27-37 \mu \mathrm{mol} \mathrm{s}{ }^{-1}$ $\mathrm{m}^{-2}$ were more suitable for the Chamaecyparis and Cupressocyparis cultivars.

\section{Temperature}

A temperature range between 18 and $27^{\circ} \mathrm{C}$ is commonly used during rooting of the cuttings. The effect of artificial light, $\mathrm{CO}_{2}$ and temperature on rooting in ornamental cultivars of Chamaecyparis, Cupressocyparis and Juniperus was studied by Kunneman and Ruesink (1997). These authors demonstrated that rooting was best at a constant temperature of $23^{\circ} \mathrm{C}$, compared with 17 and $29^{\circ} \mathrm{C}$. On the other hand, for Pinus taeda L., the best rooting of cuttings (seedlings and hedged donor plants) $(80 \%)$ was obtained by maintaining the air temperature at approximately $27^{\circ} \mathrm{C}$ during the day (14-h photoperiod) and $20^{\circ} \mathrm{C}$ at night (Hamann 1998), and the temperature of the rooting medium was kept at $25^{\circ} \mathrm{C}$ using a root zone heating system.

Cedrus spp., in general, are difficult to root, for example Cedrus libani A. Rich. is considered almost impossible to propagate by cuttings; however, Cedrus deodara (Roxb.) G.Don 'Shalimar' can be rooted to $67 \%$ if cuttings are collected in late fall to early winter and, after a quick dip in IBA solution, placed in a sand-perlite medium maintained at $24^{\circ} \mathrm{C}$ with bottom heat (Nicholson 1984 cited by Pijut 2000). In Table 1 , other examples of temperature treatments for adventitious root formation in conifer cuttings are listed.

\section{Substrates for rooting}

The blends of propagation substrates should create suitable air and drainage characteristics and remain moist, but not waterlogged during the period of time that roots are initiated. Different substrates can be used to promote rooting in conifer cuttings, the most common being vermiculite, perlite or a combination of both. However, the requirements of various species can be very different. Davidescu et al. (2003) found that propagation by cuttings of Thuja occidentalis L. 'Columna' and T. occidentalis 'Danica' was best in peat substrate in August. Six substrates were used in Picea cuttings by Mazăre et al. (2007): sand, perlite, peat, sand with perlite, sand with peat and perlite with peat, all at 1:1. The rooted cuttings were at a higher proportion in sand with peat, but increased rooting index $(13 \%$ as visually established based on the number of primary and secondary roots) was obtained in perlite with peat.

Rooting of loblolly pine ( $P$. taeda) cuttings has been extensively studied, but the description of substrates used 


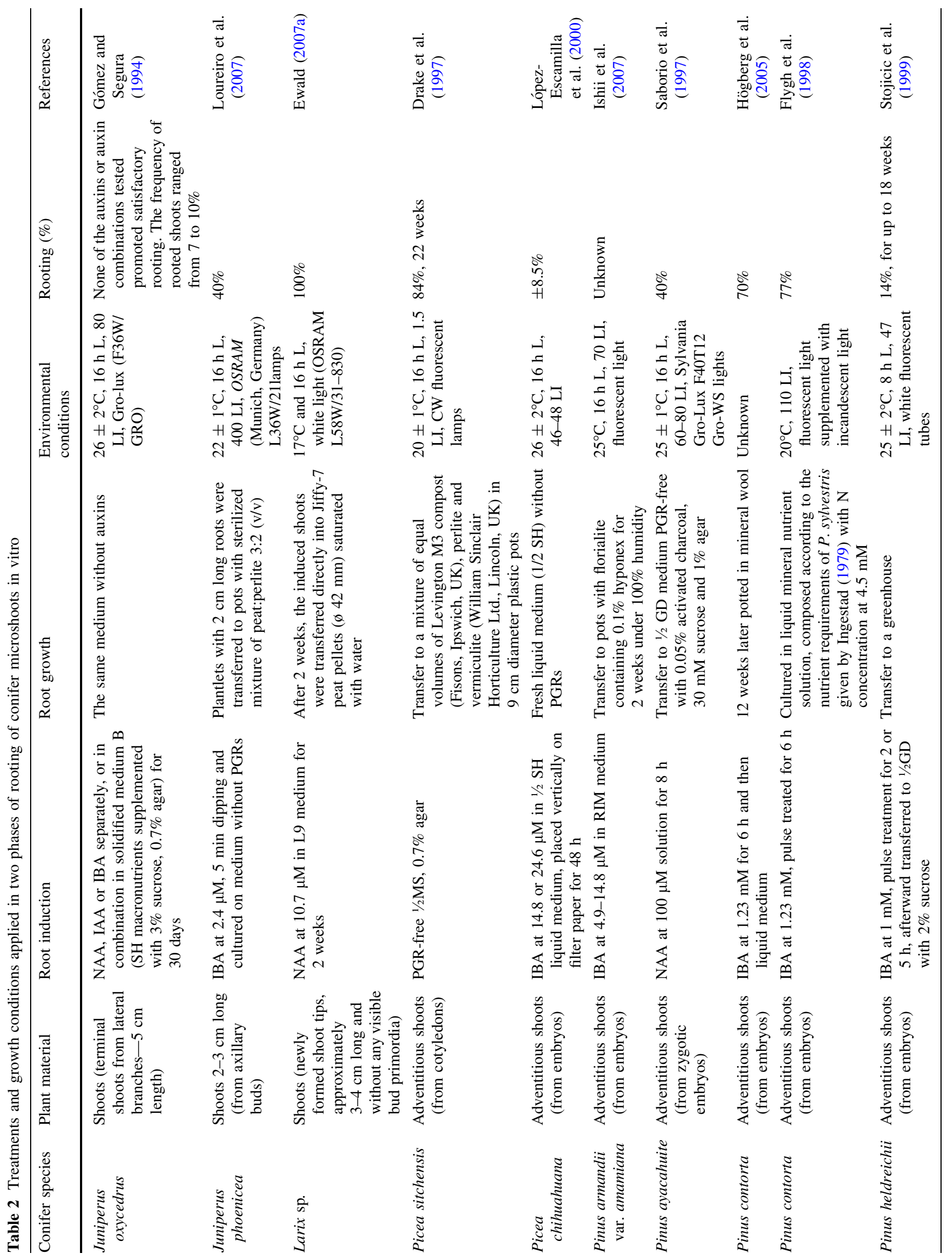




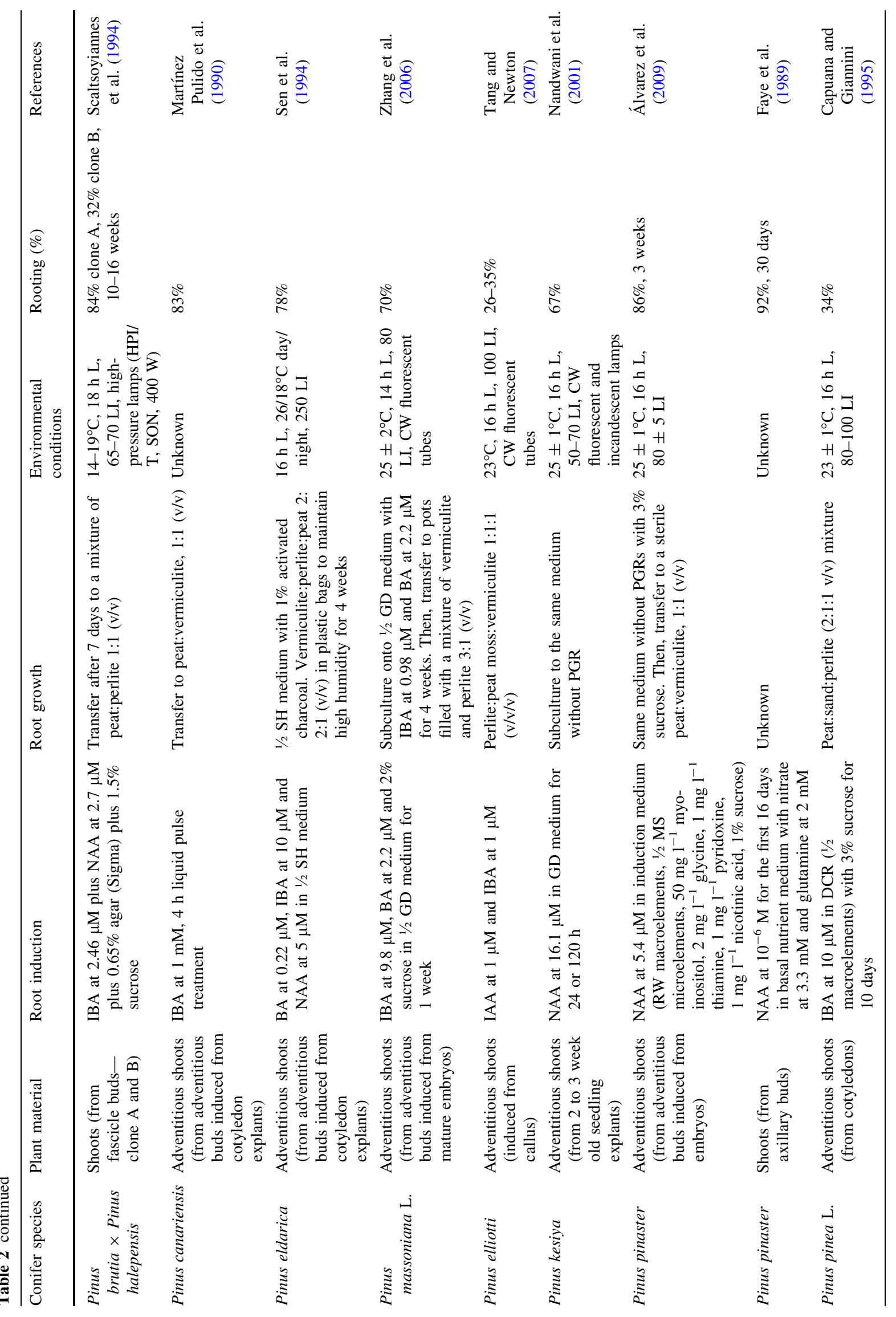




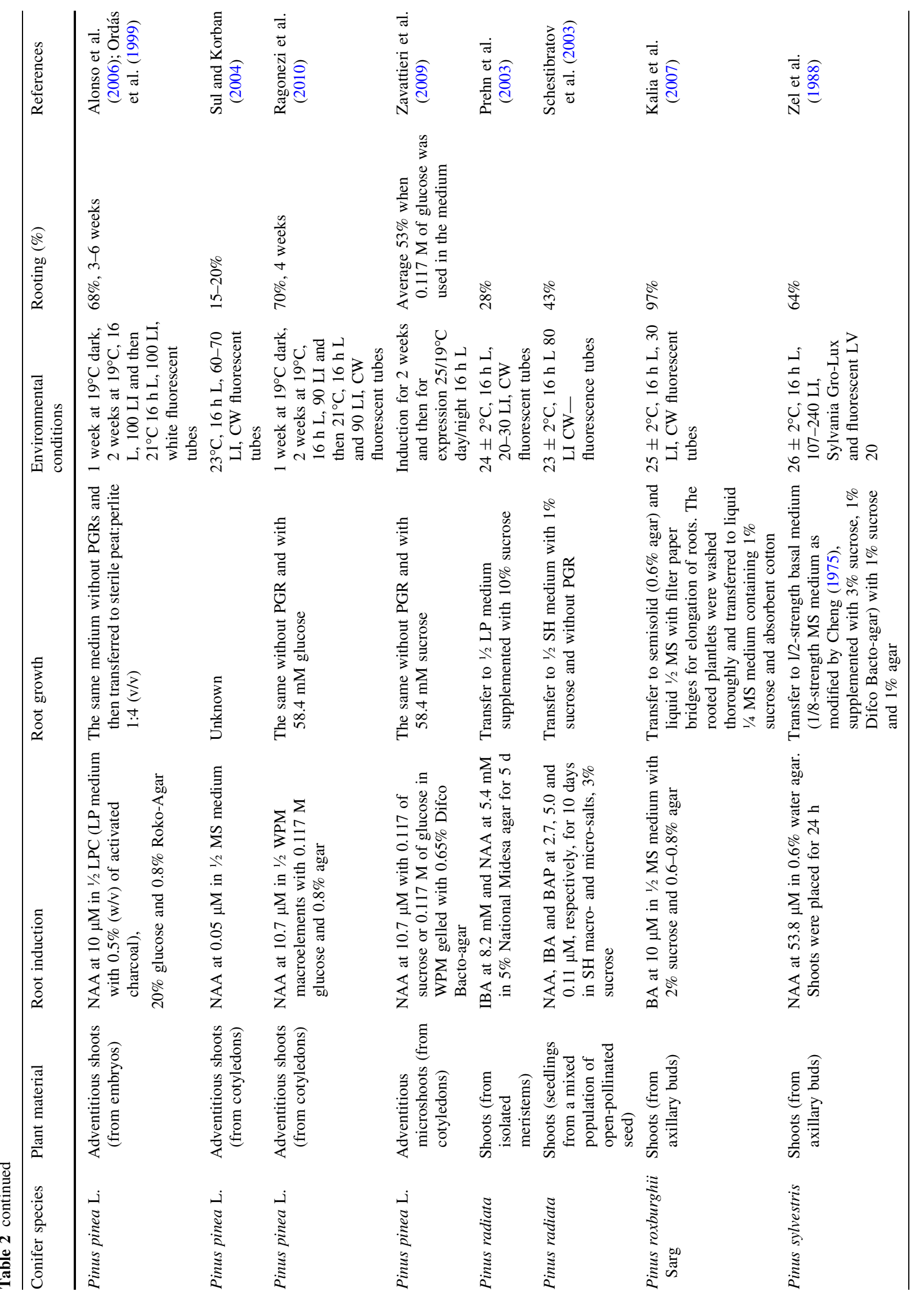




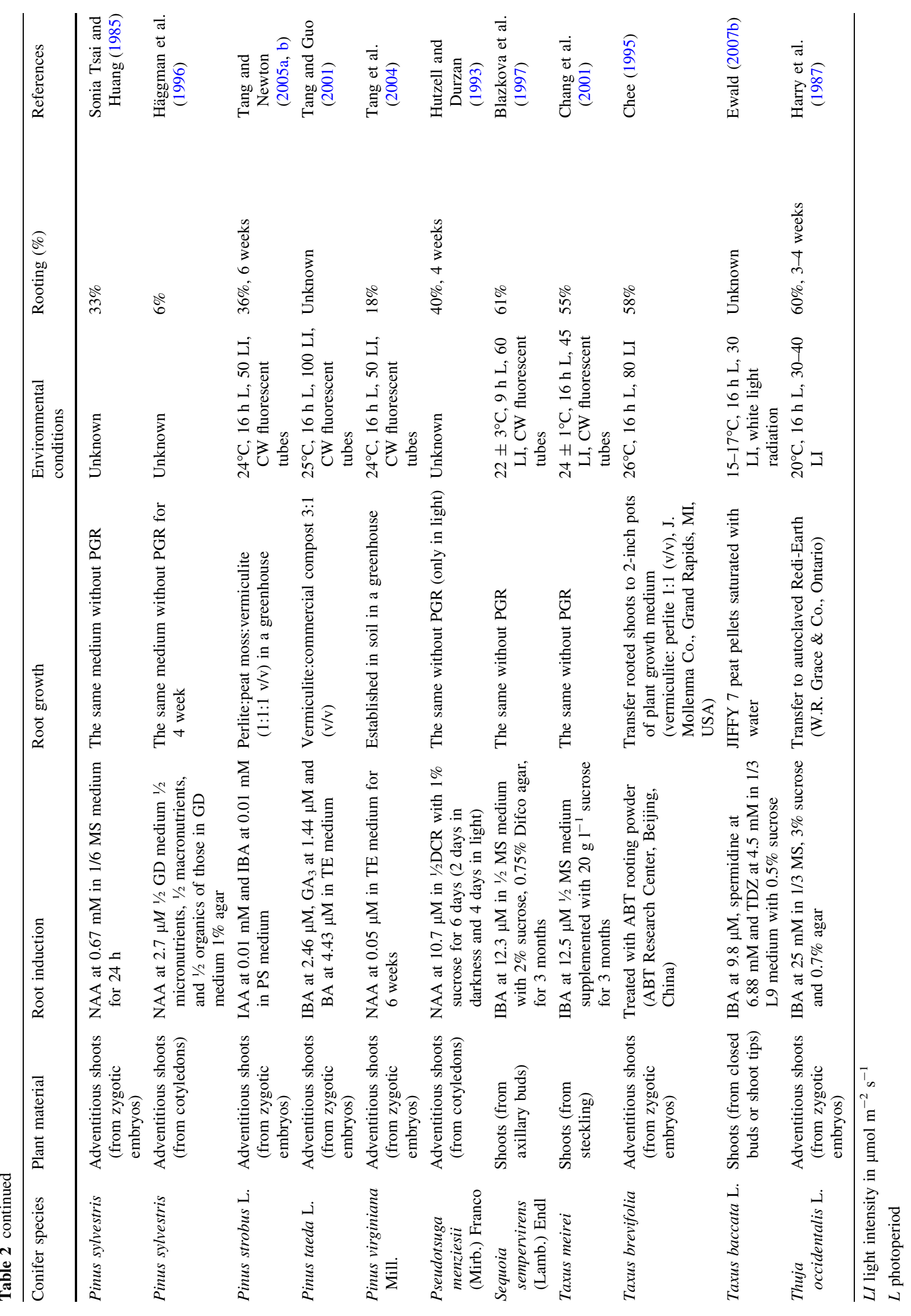


was not always included. Hamann (1998), working with this species, used a substrate consisting of equal parts of perlite and coarse vermiculite, to a depth of $1.5 \pm 2 \mathrm{~cm}$ and obtained $80 \%$ rooting. In Brazil, with the same species, the cuttings were placed in plastic tubes containing Mecplant (substrate composed of biostabilized pine bark) overlaid with vermiculite (Alcantara et al. 2007). Table 1 shows a compilation of different substrates applied to conifer cuttings.

\section{In vitro rooting of conifer microshoots}

Many basic studies on rooting are now carried out in vitro. Using seedling explants and in some cases also explants from mature trees, it has become current, in some species, to produce rooted micropropagated shoots (microcuttings) by in vitro organogenesis (Niemi et al. 2004). Tissue culture method facilitates administration of PGRs and other compounds and avoids microbial degradation of applied compounds (De Klerk et al. 1999). According to many workers, further research is required on the influence of factors such as donor plant age, genotype and type of explant, microcutting quality, auxin treatment, root system and environmental conditions on rooting and acclimatization (Fett-Neto et al. 2001; Greenwood et al. 2001; Bielenin 2003; Henrique et al. 2006). Adventitious rooting of microshoots is characterized by the same four phases as rooting of cuttings (see above).

\section{Rooting medium}

The success of plant tissue culture as a means of plant propagation is greatly influenced by the composition of the culture medium. In vitro rooting of conifer microshoots usually occurs in gelled nutrient media (mostly agar- and gellan-gum based) as substrate. This ensures the consistent distribution of PGRs, macro- and micronutrients, and also provides a better contact between shoots and substrate, resulting in more synchronous rooting (Mohammed and Vidaver 1990). However, the quality of produced roots is not always satisfactory. Gelled media probably obstruct gas exchange and inhibit the development of the vascular system in roots, as well as the production of root hairs (Skolmen and Mapes 1978). Culture media and physical supports currently used for rooting of conifer shoots are listed in Table 2. Nutrients are usually reduced to half the strength of that used for shoot production (Blazkova et al. 1997). In general, it has been reported that lower concentration of salts in the culture medium, particularly nitrogen, seems to favor the adventitious rooting of cuttings (Ordás et al. 1985). In our experience, reducing the WPM macronutrients to half strength increases significantly the percentage of rooted microshoots of Pinus pinea L. (Ragonezi et al. 2010).

Plant growth regulators

In vitro organogenesis is a complex series of events that a cell or groups of cells undergo in response to external/ internal stimuli such as phytohormones. According to Thorpe (1980), organogenesis is a developmental process that comprises (a) attainment of competence or preinduction phase, (b) induction or determination phase, and (c) expression phase or post-initiation phase. Cell/tissue responses to form adventitious roots may be different according to species, physiological status of the explants, the phase of the rooting process, and the interaction of the chemical and physical factors of the culture. Table 2 summarizes the available information in the scientific literature, including species, rooting induction treatments, culture media, physical conditions, light regimes and rooting percentages.

Most frequently, the treatments involved IBA (13 references) or NAA (15 references). For five species, a mixture of IBA either with NAA or IAA was used. On the other hand, one research report cited $97 \%$ rooted shoots of Pinus roxburghii when $10 \mu \mathrm{M}$ BA was applied before transfer to a liquid medium for root expression. In one experiment, Taxus brevifolia treated with ABT rooting powder (developed by ABT Research and Development of Chinese Academy of Forestry) produced roots in 58\% of the microshoots derived from cotyledon explants. In one case, it was possible to root $84 \%$ of the microshoots of $P$. sitchensis derived from cotyledons without any application of PGRs and by rooting directly in a substrate mix. IBA was applied at concentrations that ranged from 1 to $25 \mu \mathrm{M}$, most often between 2.5 and $14.8 \mu \mathrm{M}$, and only in one study IBA was applied at $25 \mu \mathrm{M}$. NAA concentrations varied between as low as 0.05 and $100 \mu \mathrm{M}$, with $10.7 \mu \mathrm{M}$ being the most commonly used. However, the best results were obtained with NAA at concentrations higher than $50 \mu \mathrm{M}$, while low concentrations gave poor rooting percentages. The physical support for the shoots during the root expression phase was either a substrate (16 references) or a culture medium without PGRs (18 references).

\section{Carbohydrates}

Sucrose is commonly used in tissue culture media because it is the main sugar translocated in the phloem of many plants. However, other carbohydrates such as glucose and fructose have been also used to improve organogenesis (Faye et al. 1989; Ordás et al. 1999; Zavattieri et al. 2009). The exogenous sucrose (in the presence or absence of auxin) is beneficial for the rooting of most herbaceous and 
woody plants (Haissig 1982). Generally, enrichment with sucrose improves rooting, but this has its limits, as sucrose at high concentrations tends to have negative effects, especially during the root expression phase. A negative interaction between carbohydrates and light could emerge at such high concentrations, either through transformation of added sugars into soluble and storage forms, or through altered nitrogen/sucrose or auxin/sucrose ratios (Moncou$\sin$ 1991).

In conifers, the data on the influence of carbohydrates in adventitious rooting are limited. Zavattieri et al. (2009) made a direct comparison between different carbon sources (sucrose or glucose at different concentrations) for the induction and expression phases of the adventitious roots in microshoots of Pinus pinaea. An increased number of roots per shoot and an accelerated root formation were consistently obtained using glucose. However, there were no differences in the overall frequency of rooting. Light (16-h photoperiod, $25 / 19^{\circ} \mathrm{C}$ day/night) and less sugar were beneficial for the ensuing root expression phase. Large differences in the ability to form roots were observed among clones with the rooting percentages ranging between 0 and over $75 \%$. Other examples can be found in Table 2.

\section{Light}

Plants grown in vitro have been in most cases subjected to fluorescent lamps. These fluorescent lamps have a broad emission peak in the yellow-red region of the spectrum with different spectral emissions and wavelengths from 350 to $750 \mathrm{~nm}$. However, little attention has been given to the wavelength specificity and its effect on organogenesis, especially in ARF.

Broad-spectrum CW light is often used in rooting studies conducted in vitro (Flygh et al. 1998; Stojičić et al. 1999; Zhang et al. 2006; Ishii et al. 2007; Tang and Newton 2007). Different types of light sources such as Growth-lux (GL) (Gómez and Segura 1994), high-pressure lamps (Scaltsoyiannes et al. 1994) and their combinations such as fluorescent light supplemented with incandescent light (Flygh et al. 1998) are also applied. Different light quality influenced the rooting frequencies according to the PPFD used. Under the intensity of $90 \mu \mathrm{mol} \mathrm{m} \mathrm{m}^{-2} \mathrm{~s}^{-1}$ from CW lamps, $70 \%$ microshoots of $P$. pinea rooted; however, under GL lamps, with the same intensity, rooting was $<50 \%$ (Ragonezi et al. 2010).

In the case of shoots of Sitka spruce (P. sitchensis), the rooting frequency was high $(84 \%)$ when cultivated under low illumination $\left(1.5 \mu \mathrm{mol} \mathrm{m}{ }^{-2} \mathrm{~s}^{-1}\right)$ (Drake et al. 1997), but in Juniperus phoenicea $40 \%$ of rooting was achieved under light intensity of $400 \mu \mathrm{mol} \mathrm{m}{ }^{-2} \mathrm{~s}^{-1}$. The majority of studies relating to ARF applied light intensities that varied from 60 to $80 \mu \mathrm{mol} \mathrm{m}{ }^{-2} \mathrm{~s}^{-1}$ (Gómez and Segura 1994;
Scaltsoyiannes et al. 1994; Nandwani et al. 2001; Zhang et al. 2006; Ishii et al. 2007). The influence of light (quality) on ARF in shoots of other species is listed in Table 2.

\section{Photoperiod}

A photoperiod of $16 \mathrm{~h}$ is generally used for in vitro rooting of most conifers (Anderson and Ievinsh 2002; Parasharami et al. 2003). However, different photoperiodism requirements to induce ARF have been published. As an example Burkhart and Meyer (1991), while testing the effect of GA inhibitors to promote in vitro rooting of axillary shoots of white pine (Pinus strobus L.), obtained $43 \%$ rooted shoots with a pulse treatment of NAA under a long $(18 \mathrm{~h})$ photoperiod with CW lamps at $50 \mu \mathrm{mol} \mathrm{m} \mathrm{m}^{-2} \mathrm{~s}^{-1}$. In Picea glauca (Moench) Voss, a higher percentage of shoots rooted under continuous light (Campbell and Durzan 1975).

\section{Temperature}

Most rooting protocols reported temperatures in the range of $23-27^{\circ} \mathrm{C}$ (Table 2). Apart from the example of $T$. occidentalis shoots that rooted at 60 and $10 \%$ at 25 and $20^{\circ} \mathrm{C}$, respectively (Harry et al. 1987), the lower temperature ranges tended to be beneficial in the induction of roots from shoots of many other gymnosperms. Picea glauca rooting was greater at $20 / 18^{\circ} \mathrm{C}$ day/night temperature regimes, compared with $24 / 18,20 / 15$ or $25 / 25^{\circ} \mathrm{C}$ (Rumary and Thorpe 1984); in Douglas fir, $19^{\circ} \mathrm{C}$ promoted rooting and normal plants, while at $24^{\circ} \mathrm{C}$ few roots formed along with callus at the stem/root junction, causing discontinuity in the vascular system (Cheng 1977). In white pine ( $P$. strobus), the highest rooting frequency was obtained after elongated shoots were treated at $4^{\circ} \mathrm{C}$ for 4 weeks (Tang and Newton 2005a). The positive effect of combining low temperature and darkness in the induction phase (for the first 2 weeks) was observed in $P$. pinea L., which rooted at a higher percentage at $19^{\circ} \mathrm{C}$ compared with $25^{\circ} \mathrm{C}$ (Ragonezi et al. 2010). This is in agreement with the results reported for $P$. menziesii (Cheng and Voqui 1977) and P. radiata (Smith 1986). A possible explanation for the effect of low temperature and darkness in promoting ARF was given by Hartmann et al. (2002). They noted that under these physical environmental conditions, fewer cell wall deposits, less vascular tissue and thinner walls might have facilitated the movements of exogenous PGRs to regeneration sites. In loblolly pine (P. taeda), Hutchison et al. (1999) observed that during the first 2 days of the rooting process the cambium layer of the hypocotyls dedifferentiated into parenchyma cells in both hypocotyls and epicotyls. Since dedifferentiation 
is a part of the regeneration process (Christianson and Warnick 1983), a higher proportion of already undifferentiated cells may improve shoot or root organogenesis. A possible effect of low temperature and darkness could be explained by their influence on auxin metabolism in relation to rooting through modification of peroxidase activities and formation of endogenous phenolic compounds (Druart et al. 1982).

\section{Conclusions}

Although difficult to unify, the research results covered in this review highlight some tentative suggestions to explore the physicochemical variables in experimental rooting of conifers, as a guideline for development of more effective conditions for each species. This review also shows the difficulty in establishing correlations between species, PGR concentrations and treatments or any other of the variables cited.

However, an ongoing research on elucidating important aspects of ARF signaling network in angiosperms should eventually provide a better understanding of the process and aid in developing efficient rooting protocols. Whether the same or similar molecular events will be identified in conifers, the evolutionary and physiologically different organisms, remains unknown. A study undertaken by Brinker et al. (2004) in P. contorta showed that the transcription level of 200 genes changed from root induction to development suggesting a complex network of interactions in this conifer species.

Acknowledgments This work was supported by FCT Portugal: PTDC/AGR-CFL/71437/2006 Analysis and Mastering of Root Growth Signalling by Ectomycorrhizal Fungi on $P$. pinea L. Microshoot Cultures. Ms. P. Cheers (Canadian Forest Service-Laurentian Forestry Centre) is gratefully acknowledged for English editing.

\section{References}

Abo El-Nil MM (1982) Method for asexual reproduction of coniferous trees. US Patent No. 4,353,184

Alcantara GB, Fortes Ribas LL, Rioyei HA, Zuffellato Ribas KC, Soares Koehler H (2007) Efeito da idade da muda e da estação do ano no enraizamento de miniestacas de Pinus taeda L. Rev Árvore [online] 31:399-404. doi:10.1590/S0100-67622007000300005

Alonso P, Moncaléan P, Fernández B, Rodríguez A, Centeno ML, Ordás RJ (2006) An improved micropropagation protocol for stone pine (Pinus pinea L.). Ann For Sci 63:879-885. doi: 10.1051/forest:2006071

Álvarez JM, Majada J, Ordás RJ (2009) An improved micropropagation protocol for maritime pine (Pinus pinaster Ait.) isolated cotyledons. Forestry 82:175-184. doi:10.1093/forestry/cpn052

Anderson U, Ievinsh G (2002) Changes of morphogenic competence in mature Pinus sylvestris L. buds in vitro. Ann Bot 90:293-298. doi:10.1093/aob/mcf176
Arteca RN (1995) Plant growth substances principles and applications. Chapman and Hall, New York, p 288

Beyer EM (1976) A potent inhibitor of ethylene action in plants. Plant Physiol 58:268-271

Biddington NL (1992) The influence of ethylene in plant tissue culture. Plant Growth Regul, The Hague 11:173-187

Bielenin M (2003) Rooting and gas exchange of conifer cuttings treated with indolebutyric acid. J Fruit Ornam Plant Res 11:99-105

Blazkova A, Sotta B, Tranvan H, Maldiney R, Bonnet M, Einhorn J, Kerhoas L, Miginiac E (1997) Auxin metabolism and rooting in young and mature clones of Sequoia sempervirens. Physiol Plant 99:73-80

Bollmark M, Eliasson L (1990) Ethylene accelerates the breakdown of cytokinins and thereby stimulates rooting in Norway spruce hypocotyl cuttings. Physiol Plant 80:534-540. doi:10.1111/j. 1399-3054.1990.tb05675.x

Brinker M, van Zyl L, Liu W, Craig D, Sederoff RR, Clapham DH, von Arnold S (2004) Microarray analyses of gene expression during adventitious root development in Pinus contorta. Plant Physiol 135:1526-1539. doi:10.1104/pp.103.032235

Browne RD, Davidson CG, Steeves TA, Dunstan DI (1996) Effects of ortet age on adventitious rooting of jack pine (Pinus banksiana) long-shoot cuttings. Can J For Res 27:91-96. doi:10.1139/cjfr27-1-91

Browne RD, Davidson CG, Enns SM (2000) Improvements in asexual multiplication procedures for jack pine (Pinus banksiana). New For 19:259-278

Burkhart LF, Meyer MM Jr (1991) The gibberellin synthesis inhibitors, ancymidol and flurprimidol, promote in vitro rooting of white pine microshoots. Plant Cell Rep 10:475. doi: 10.1007/BF00233818

Campbell RA, Durzan DJ (1975) Induction of multiple buds and needles in tissue cultures of Picea glauca. Can J Bot 53: $1652-1657$

Capuana M, Giannini R (1995) In vitro plantlet regeneration from embryonic explants of Pinus pinea L. In Vitro Cell Dev Biol Plant 31:202-206. doi:10.1007/BF02632022

Chang SH, Ho CK, Chen ZZ, Tsay JY (2001) Micropropagation of Taxus mairei from mature trees. Plant Cell Rep 20:496-502. doi: 10.1007/s002990100362

Chee PP (1995) Organogenesis in Taxus brevifolia tissue cultures. Plant Cell Rep 14:560-565. doi:10.1007/BF00231938

Cheng TY (1975) Adventitious bud formation in culture of Douglas fir (Pseudotsuga menziesii (Mirb.) Franco). Plant Sci Lett 5:97-102

Cheng TY (1977) Factors affecting adventitious bud formation of cotyledon culture of Douglas fir. Plant Sci Lett 9:179-187

Cheng TY, Voqui TH (1977) Regeneration of Douglas fir plantlets through tissue culture. Science 198:306-307. doi:10.1126/ science.198.4314.306

Christianson ML, Warnick DA (1983) Competence and determination in the process of in vitro shoot organogenesis. Dev Biol 95: $188-193$

Clark DG, Gubrium EK, Barrett JE, Nell TA, Klee HJ (1999) Root formation in ethylene-insensitive plants. Plant Physiol 121: $53-59$

Copes DL, Mandel NL (2000) Effect of IBA and NAA treatments on rooting Douglas-fir stem cuttings. New For 20:249-257. doi: 10.1023/A:1006752717350

Corrêa LR, Fett-Neto AG (2004) Effects of temperature on adventitious root development in microcuttings of Eucalyptus saligna Smith and Eucalyptus globulus Labill. J Therm Biol 29:315-324. doi:10.1016/j.jtherbio.2004.05.006

Corrêa LR, Paim DC, Schwambach J, Fett-Neto AG (2005) Carbohydrates as regulatory factors in the rooting of Eucalyptus 
saligna Smith and Eucalyptus globulus Labill. Plant Growth Regul 45:63-73

Couée I, Hummel I, Sulmon C, Gouesbet G, El Amrani A (2004) Involvement of polyamines in root development. Plant Cell Tiss Org Cult 76:1-10

Davidescu VE, Caretu G, Madjar RM, Stanica F, Peticila AG, Dumitrascu M (2003) The influence of substrate and cutting period on the propagation of some ornamental species. Acta Hortic 608:273-277. http://www.actahort.org/books/608/608_ 34.htm

Davis TD, Haissig BE (1990) Chemical control of adventitious root formation in cuttings. Plant Growth Regul Soc Am Q 18:1-18

Davis TD, Haissig BE, Sankhla N (1988) Adventitious root formation in cuttings. Adv Plant Sci 2:174-182

De Klerk GJ, Ter Brugge J, Marinova S (1997) Effectiveness of indoleacetic acid, indolebutyric acid and naphthaleneacetic acid during adventitious root formation in vitro in Malus 'Jork 9'. Plant Cell Tissue Organ Cult 49:39-44. doi:10.1023/A:1005850222973

De Klerk GJ, Van der Krieken W, De Jong JC (1999) The formation of adventitious roots: new concepts, new possibilities. In Vitro Cell Dev Biol Plant 35:189-199. doi:10.1007/s11627-999-0076-Z

De Silva H, Mc Kenzie BA, Bloomberg M (2005) Indolebutyric acid and wounding induced rooting in callused, non-rooted Leyland cypress $(\times$ Cupressocyparis leylandii) stem cuttings. NZ J Crop Hortic Sci 33:407-412. doi:0014-0671/05/3304-0407

Diaz-Sala C, Hutchison K, Goldfarb B, Greenwood MS (1996) Maturation-related loss of rooting competence by loblolly pine stem cuttings: the role of auxin transport, metabolism and tissue sensitivity. Physiol Plant 97:481-490. doi:10.1111/j.1399-3054. 1996.tb00507.x

Drake PMW, John A, Power JB, Davey MR (1997) Cytokinin pulsemediated shoot organogenesis from cotyledons of Sitka spruce [Picea sitchensis (Bong.) Carr.] and high frequency in vitro rooting of shoots. Plant Cell Tissue Organ Cult 50:147-151. doi: 10.1023/A:1005998812774

Druart PH, Kevers CL, Gaspar TH (1982) In vitro promotion of root formation by apple shoots through darkness effect on endogenous phenols and peroxidases. Z Pflazen Physiol 108:429-436

Ewald D (2007a) Micropropagation of Larix species via organogenesis. In: Jain SM, Häggman H (eds) Protocols for micropropagation of woody trees and fruits. Springer, Dordrecht, pp 125-136. doi:10.1007/978-1-4020-6352-712

Ewald D (2007b) Micropropagation of yew (Taxus baccata L.). In: Jain SM, Häggman H (eds) Protocols for micropropagation of woody trees and fruits. Springer, Dordrecht, pp 117-123. doi: $10.1007 / \mathrm{s} 002990100362$

Farjon A (1998) World checklist and bibliography of conifers. Royal Botanical Gardens, Kew

Faye M, Ourry A, Saidali-Savi C, Dargent R, Boucaud J, David A (1989) Effects of glutamine and K-glutamate on assimilation of nitrate during auxin treatment for root formation in vitro (Pinus pinaster). Physiol Plant 76:277-282. doi:10.1111/j.1399-3054. 1989.tb06191.x

Fett-Neto AG, Fett JP, Goulart LWV, Pasquali G, Termignoni RR, Ferreira AG (2001) Distinct effects of auxin and light on adventitious root development in Eucalyptus saligna and Eucalyptus globulus. Tree Physiol 21:457-464. doi:10.1093/ treephys/21.7.457

Flygh G, Grönroos R, Hogberg KA, von Arnold S (1998) Development and growth of plantlets of Pinus contorta regenerated from adventitious buds. Scand J For Res 13:331-339. doi: $10.1080 / 02827589809382992$

Gahan PB (2007) Totipotency and the cell cycle. In: Jain SM, Häggman $\mathrm{H}$ (eds) Protocols for micropropagation of woody trees and fruits. Springer, Dordrecht, pp 3-14
Gaspar T, Coumans M (1987) Root formation. In: Bonga JM, Durzan DJ (eds) Cell and tissue culture in forestry. Martinus Nijhoff Publishers, The Hague, pp 202-217

Goldfarb B, Hackett WP, Furnier GR, Mohn CA, Plietzsc A (1998) Adventitious root initiation in hypocotyls and epicotyl cuttings of eastern white pine (Pinus strobus) seedlings. Physiol Plant 102:513-522. doi:10.1034/j.1399-3054.1998.1020405.x

Gómez MP, Segura J (1994) Axillary shoot proliferation in cultures of explants from mature Juniperus oxycedrus trees. Tree Physiol 15:625-628. doi:10.1093/treephys/15.9.625

Greenwood MS, Hutchison KW (1993) Maturation as a developmental process. In: Ahuja MR, Libby WJ (eds) Clonal forestry. I. Genetics and biotechnology. Springer, New York, pp 14-33

Greenwood MS, Weir RJ (1994) Genetic variation in rooting ability of loblolly pine cuttings: effects of auxin and family on rooting by hypocotyl cuttings. Tree Physiol 15:41-45. doi:10.1093/ treephys/15.1.41

Greenwood MS, Cub K, Xu F (2001) Response to auxin changes during maturation-related loss of adventitious rooting competence in loblolly pine (Pinus taeda) stem cuttings. Physiol Plant 111:373-380. doi:10.1111/j.1399-3054.2001.1110315.x

Gresshoff PM, Doy CH (1972) Development and differentiation of haploid Lycopersicon esculentum (tomato). Plant 17:161-170. doi:10.1007/BF00387721

Gupta PK, Durzan DJ (1985) Shoot multiplication from mature Douglas-fir and sugar pine. Plant Cell Rep 4:177-179

Häggman H, Aronen T, Stomp A-M (1996) Early-flowering Scots pines through tissue culture for accelerating tree breeding. Theor Appl Genet 93:840-848

Haissig BE (1982) Carbohydrate and amino acid concentrations during adventitious root primordium development in Pinus banksiana Lamb. cuttings. For Sci 28:813-821

Haissig BE (1990) Reduced irradiance and applied auxin influence carbohydrate relations in Pinus banksiana cuttings during propagation. Physiol Plant 78:455-461. doi:10.1111/j.13993054.1990.tb09063.x

Hamann A (1998) Adventitious root formation in cuttings of loblolly pine (Pinus taeda L.): developmental sequence and effects of maturation. Trees 12:175-180. doi:10.1007/PL00009707

Hansen J, Ernstsen A (1982) Seasonal changes in adventitious root formation in hypocotyl cuttings of Pinus sylvestris: influence of photoperiod during stock plant growth and of indolebutyric acid treatment of cuttings. Physiol Plant 54:99-106

Harry IS, Thompson MR, Lu CY, Thorpe TA (1987) In vitro plantlet formation from embryonic explants of eastern white cedar (Thuja occidentalis L.). Tree Physiol 3:273-283. doi:10.1093/ treephys/3.3.273

Hartmann HT, Kester DE (1983) Anatomical and physiological basis of propagation by cuttings. In: Plant propagation: principles and practices. Prentice-Hall Inc., Englewood Cliffs, pp 235-297

Hartmann HT, Kester DE, Davis FT Jr, Geneve RL (2002) Plant propagation: principles and practices, 7 th edn. Prentice-Hall Inc., Englewood Cliffs

Henrique A, Campinhos EN, Ono EO, Pinho SZ (2006) Effect of plant growth regulators in the rooting of Pinus cuttings. Braz Arch Biol Technol 49:189-196

Högberg K (2005) Rooting response of late summer cuttings taken from Pinus sylvestris half-sib families. Scand J For Res 20:313-317. doi:10.1080/02827580510036382

Högberg K, Flygh G, Grönroos R, von Arnold S (2005) Field performance of Pinus contorta trees propagated vegetatively via adventitious buds. Scand J For Res 20:318-321. doi:10.1080/ 02827580510036247

Hutchison KW, Singer PB, McInnis S, Diaz-Sala C, Greenwood MS (1999) Expansins are conserved in conifers and expressed in 
hypocotyls in response to exogenous auxin. Plant Physiol 120:827-832

Hutzell MJ, Durzan DJ (1993) Improved aseptic germination and controlled growth for micropropagation of Douglas fir. In: Ahuja MR (ed) Micropropagation of woody plants. Kluwer, Dordrecht, pp 367-372

Ingestad T (1979) Mineral nutrient requirements of Pinus sylvestris and Pinus abies seedlings. Physiol Plant 45:373-380

Ishii K, Hosoi Y, Maruyama E (2007) Micropropagation of Pinus armandii var. amamiana. In: Jain SM, Häggman H (eds) Protocols for micropropagation of woody trees and fruits. Springer, Dordrecht, pp 41-50. doi:10.1007/978-1-40206352-7_5

Kalia RK, Arya S, Kalia S, Arya ID (2007) Plantlet regeneration from fascicular buds of seedling shoot apices of Pinus roxburghii Sarg. Biol Planta 51:653-659. doi:10.1007/s10535-007-0138-1

Kaur-Sawhney R, Tiburcio AF, Atabella T, Galston AW (2003) Polyamines in plants: an overview. J Cell Mol Biol 2:1-12

Klimaszewska K, Trontin J-F, Becwar MR, Devillard C, Park Y-S, Lelu-Walter M-A (2007) Recent progress in somatic embryogenesis of four Pinus spp. Glob Sci Books Tree For Sci Biotechnol 1:11-25

Krouk G, Lacombe B, Bielach A, Perrine-Walker F, Malinska K, Mounier E et al (2010) Nirate-regulated auxin transport by NRT1.1 defines a mechanism for nutrient sensing in plants. Dev Cell 18:927-937. doi:10.1016/j.devcel.20101.05.008

Kumar PP, Lakshmanan P, Thorpe TA (1998) Regulation of morphogenesis in plant tissue culture by ethylene. In Vitro Cell Dev Biol Plant 34:94-103

Kummerow J (1966) Vegetative propagation of Pinus radiata by means of needle fascicles. For Sci 12:391-398

Kunneman BPAM, Ruesink JB (1997) Interactions between light, temperature and $\mathrm{CO}_{2}$ in rooting of conifers cuttings. Acta Hortic 418:97-102. http://www.actahort.org/books/418/418_12.htm

Lamhamedi MS, Tousignant D (2008) Clonal variations in Picea abies stock plants produced by somatic embryogenesis and their use in cutting propagation programs. In: IUFRO-CTIA 2008 joint conference-adaptation, breeding and conservation in the era of forest tree genomics and environmental change, Québec, QC, 25-28 August 2008

Li M, Leung DWM (2000) Starch accumulation is associated with adventitious root formation in hypocotyl cuttings of Pinus radiata. J Plant Growth Regul 19:423-428. doi:10.1007/ s003440000020

Li SW, Xue L (2010) The interaction between $\mathrm{H}_{2} \mathrm{O}_{2}$ and $\mathrm{NO}, \mathrm{Ca}^{2+}$, and cGMP, and MAPKs during adventitious rooting in mung bean seedlings. In Vitro Cell Dev Biol Plant 46:142-148. doi: 10.1007/s11627-009-9275-x

Li SW, Xue L, Xu S, Feng H, An L (2009) Mediators, genes and signaling in adventitious rooting. Bot Rev 75:230-247. doi: 10.1007/s12229-009-9029-9

Libby WJ (1986) Clonal propagation. J For 84:37-45

Lindroth AM, Saarikoski P, Flygh G, Clapham D, Grönroos R, Thelander M, Ronne H, von Arnold S (2001) Two sadenosylmethionine synthetase-encoding genes differentially expressed during adventitious root development in Pinus contorta. Plant Mol Biol 46:335-346. doi:10.1023/A:1010637012528

Lloyd G, McCown B (1981) Commercially feasible micropropagation of mountain laurel, Kalmia latifolia, by the use of shoot tip culture. Proc Plant Prop Soc 30:421-427

López-Escamilla AL, Olguín-Santos LP, Márquez J, Chávez VM, Bye R (2000) Adventitious bud formation from mature embryos of Picea chihuahuana Martínez, an endangered Mexican spruce tree. Ann Bot 86:921-927. doi:10.1006/anbo.2000.1257

Loureiro J, Capelo A, Brito G, Rodriguez E, Silva S, Pinto G, Santos C (2007) Micropropagation of Juniperus phoenicea from adult plant explants and analysis of ploidy stability using flow cytometry. Biol Plant 51:7-14. doi:10.1007/s10535-007-0003-2

Martínez Pulido C, Harry IS, Thorpe TA (1990) In vitro regeneration of plantlets of Canary Island pine (Pinus canariensis). Can J For Res 20:1200-1211. doi:10.1139/x90-159

Martinez-Pastur G, Arena ME, Benavides MP, Eliasco E, Curvetto N (2007) Role of polyamines during in vitro rhizogenesis of Nothofagus nervosa using successive culture media. New For 34:83-93

Martin-Tanguy J (2001) Metabolism and function of polyamines in plants: recent development (new approaches). Plant Growth Regul 34:135-148

Martin-Tanguy J, Carré M (1993) Polyamines in grapevine microcuttings cultivated in vitro: effects of amines and inhibitors of polyamine biosynthesis on polyamine levels and microcutting growth and development. Plant Growth Regul 13:269-280

Mazăre G, Dumitraş A, Zaharia D, Holonec L, Ceuca V, Timofte A (2007) The obtaining of Picea cultivars by cuttings. Bulletin of University of Agricultural Sciences and Veterinary Medicine, Cluj-Napoca. Horticulture 64:277-281

McClelland MT, Smith MAL, Carothers ZB (1990) The effects of in vitro and ex vitro root initiation on subsequent microcutting root quality in three woody plants. Plant Cell Tissue Organ Cult 23:115-123

Menzies MI, Holden DG, Klomp BK (2001) Recent trends in nursery practice in New Zealand. New For 22:3-17. doi:10.1023/A: 1012027013173

Moe R, Andersen AS (1988) Stock plant environment and subsequent adventitious rooting. In: Davis TD, Haissig BE, Sankhla N (eds) Adventitious root formation in cuttings. Advances in plant sciences series, vol 2. Dioscorides Press, Portland, pp 214-234

Mohammed GH, Vidaver WE (1988) Root production and plantlet development in tissue-cultured conifers. Plant Cell Tissue Organ Cult 14:137-160

Mohammed GH, Vidaver WE (1990) The influence of acclimatization treatment and plantlet morphology on early greenhouse performance of tissue-cultured Douglas fir [Pseudotsuga menziesii (Mirb) Franco]. Plant Cell Tissue Organ Cult 21:111-117. doi: 10.1007/BF00033429

Moncousin CH (1991) Rooting of in vitro cuttings. In: Bajaj YPS (ed) Biotechnology in agriculture and forestry. Springer, Berlin, pp 231-261

Mudge KW (1988) Effect of ethylene on rooting. In: Davis TD, Haissig BE, Sankhla N (eds) Adventitious root formation in cuttings. Advances in plant sciences series, vol 2. Dioscorides Press, Portland, pp 150-161

Murashige T, Skoog F (1962) A revised medium for rapid growth and bio-assays with tobacco tissue cultures. Physiol Plant 15:473-497

Nandwani D, Kumaria S, Tandon P (2001) Micropropagation of Pinus kesiya Royle ex Gord (Khasi pine). Gartenbauwissenschaft 66:68-71

Nicholson R (1984) Propagation notes Cedrus deodara 'Shalimar' and Calocedrus decurrens. Plant Prop 30:5-6

Nicholson R, Garcia B, McDaniel B, MacRay C (1999) Observations on the propagation of Cupressus dupreziana Camus, an endemic Saharan Gymnosperm. Bot Gard Conserv News 3:49-50

Niemi K, Scagel C, Häggman H (2004) Application of ectomycorrhizal fungi in vegetative propagation of conifers. Plant Cell Tissue Organ Cult 78:83-91. doi:10.1023/B:TICU.00000 20379.52514 .72

Nordström AC, Jacobs FA, Eliasson L (1991) Effect of exogenous indole-3-acetic acid and indole-3-butyric acid on internal levels of the respective auxins and their conjugation with aspartic acid during adventitious root formation in pea cuttings. Plant Physiol 96:856-861 
Ordás RJ, Rodríguez A, Rodríguez R, Sánchez R (1985) Desarrollo de técnicas de cultivo "in vitro" para la micropropagación de variedades de manzana sidrera. Edafol Agrobiotecnol 43:905-917

Ordás RJ, Alonso P, Cuesta C, Cortizo M, Rodríguez A, Fernández B (1999) Micropropagation of Pinus pinea L. In: Jain SM, Häggman $\mathrm{H}$ (eds) Protocols for micropropagation of woody trees and fruits. Springer, Dordrecht, pp 33-39

Pâques LE, Cornu D (1991) Effect of vegetative propagation on field performance up to age 8 of hybrid larch (Larix $\times$ eurolepsis) clones. Ann Sci For 48:469-482

Parasharami VA, Poonawala IS, Nadgauda RS (2003) Bud break and plantlet regeneration in vitro from mature trees of Pinus roxburghii Sarg. Curr Sci 84:203-208

Pijut PM (2000) Cedrus-the true cedars. J Arboric 26:218-224

Prehn D, Serrano C, Mercado A, Stange C, Barrales L, Arce-Johnson P (2003) Regeneration of whole plants from apical meristems of Pinus radiata. Plant Cell Tissue Organ Cult 73:91-94. doi: 10.1023/A:1022615212607

Quorin M, Lepoivre P (1977) Études de milieux adaptes aux cultures in vitro de Prunus. Acta Hortic 78:437-442

Ragonezi C, Castro MR, Klimaszewska K, Lima M, Zavattieri MA (2010) Influence of light quality and intensity on adventitious root formation in microshoots of Pinus pinea L. Acta Hort 865:287-291. http://www.actahort.org/books/865/865_38.htm

Rasmussen A, Smith TE, Hunt MA (2009) Cellular stages of root formation, root system quality and survival of Pinus elliottii var. elliottii $\times P$. caribaea var. hondurensis cuttings in different temperature environments. New For 38:285-294. doi:10.1007/ s11056-009-9147-6

Risser PG, White PR (1964) Nutritional requirements of spruce tumor cells in vitro. Physiol Plant 17:620-635

Ritchie GA (1991) The commercial use of conifer rooted cuttings in forestry: a world overview. New For 5:247-275. doi:10.1007/ BF00028115

Rosier CL, Frampton J, Goldfarb B, Wise FC, Blazich FA (2004a) Growth stage, auxin type, and concentration influence rooting of stem cuttings of Fraser fir. HortScience 39:1397-1402

Rosier CL, Frampton J, Goldfarb B, Wise FC, Blazich FA (2004b) Growth stage, auxin type, and concentration influence rooting of virginia pine stem cuttings. HortScience 39:1392-1396

Rumary C, Thorpe TA (1984) Plantlet formation in black and white spruce. I. In vitro techniques. Can J For Res 14:10-16. doi: 10.1139/x84-002

Saborio F, Dvorak WS, Donahue JK, Thorpe TA (1997) In vitro regeneration of plantlets from mature embryos of Pinus ayacahuite. Tree Physiol 17:787-796

Scagel CF, Linderman RG (2000) Changes in root IAA content and growth of bare root conifers treated with plant growth regulating substances at planting. J Environ Hortic 18:99-107

Scagel CF, Linderman RG, Scagel RK (2000) Ten-year growth and survival of Douglas-fir seedlings treated with plant growth regulating substances at transplant. Can J For Res 30:1778-1787. doi:10.1139/cjfr-30-11-1778

Scaltsoyiannes A, Panetsos K, Economou A, Tsoulpha P (1994) Micropropagation of the pine hybrid Pinus brutia (Ten) $\times$ Pinus halepensis (Mill) by culturing fascicle shoots. Ann Sci For 51:175-182. doi:10.1051/forest:19940207

Schenk RU, Hildebrandt AC (1972) Medium and techniques for induction and growth of monocotyledonous and dicotyledonous plant cell cultures. Can J Bot 50:199-204

Schestibratov KA, Mikhailov RV, Dolgov SV (2003) Plantlet regeneration from subculturable nodular callus of Pinus radiata. Plant Cell Tiss Org Cult 72:139-146

Selby C, Kennedy SJ, Harvey BMR (1992) Adventitious root formation in hypocotyl cuttings of Picea sitchensis (Bong.)
Carr.-the influence of plant growth regulators. New Phytol 120:453-457

Sen S, Magallanes-Cedeno ME, Kamps RH, McKinley CR, Newton RJ (1994) In vitro micropropagation of Afghan pine. Can J For Res 24:1248-1252

Shamet GS, Bhardwaj SD (1995) Vegetative propagation of deodar, spruce, and silver-fir using stem cuttings under intermittent mist. Van Vigyan 33:80-84

Shigehiro Y (2006) Effect of plant growth retardant (daminozide wettable powder) to control elongation of seedlings of Cryptomeria japonica and C. chamaecyparis obtuse. Bull Shizuoka Prefecture. For For Prod 34:1-6

Silva AA (1985) Propagação vegetativa em Pinus spp. Silvicultura 2:141

Skolmen RG, Mapes MO (1978) Aftercare procedures required for field survival of tissue culture propagated Acacia koa. Comb Proc Int Plant Prop Soc 28:156-164

Smith DR (1986) Forest and nut trees. In: Bajaj YPS (ed) Biotechnology in agriculture and forestry. Trees, vol 1. Springer, Berlin, pp 274-289

Sonia Tsai HC, Huang FH (1985) Vegetative propagation of Scots pine (Pinus sylvestris L.) through tissue culture. In: Proceedings of 18th southern forest tree improvement conference, Long Beach, MS, v. 18

Stojičić D, Budimir S, Ćulafić L (1999) Micropropagation of Pinus heldreichii. Plant Cell Tissue Organ Cult 59:147-150. doi: 10.1023/A:1006373218772

Stumpf ERT, Grolli P, Silva JAG (1999) Rooting of Chamaecyparis lawsoniana PARL. Cuttings with indolbutyric acid in five media. Ciênc Rural 29:207-211. doi:10.1590/S0103-84781999000 200004

Sul W, Korban SS (2004) Effects of salt formulations, carbon sources, cytokinins, and auxin on shoot organogenesis from cotyledons of Pinus pinea L. J Plant Growth Regul 43:197-205. doi: 10.1023/B:GROW.0000046013.47892.4f

Sutton B (2002) Commercial delivery of genetic improvement to conifer plantations using somatic embryogenesis. Ann For Sci 59:657-661. doi:0.1051/forest:2002052

Tang W, Guo Z (2001) In vitro propagation of loblolly pine via direct somatic organogenesis from mature cotyledons and hypocotyls. J Plant Growth Regul 33:25-31. doi:10.1023/A: 1010764816523

Tang W, Newton RJ (2005a) Plant regeneration from callus cultures derived from mature zygotic embryos in white pine (Pinus strobus L.). Plant Cell Rep 24:1-9. doi:10.1007/s00299005-0914-3

Tang W, Newton RJ (2005b) Polyamines promote root elongation and growth by increasing root cell division in regenerated Virginia pine (Pinus virginiana Mill) plantlets. Plant Cell Rep 24: 581-589

Tang W, Newton RJ (2007) Micropropagation via organogenesis in slash pine. In: Jain SM, Häggman $\mathrm{H}$ (eds) Protocols for micropropagation of woody trees and fruits. Springer, Dordrecht, pp 15-22. doi:10.1007/978-1-4020-6352-7_2

Tang W, Ouyang F, Guo ZC (1998) Plant regeneration through organogenesis from callus induced from mature zygotic embryos of loblolly pine. Plant Cell Rep 17:557-560

Tang W, Harris LC, Outhavong V, Newton RJ (2004) The effect of different plant growth regulators on adventitious shoot formation from Virginia pine (Pinus virginiana) zygotic embryo explants. Plant Cell Tissue Organ Cult 78:237-240. doi:10.1023/B:TICU. 0000025658.73970 .57

Tarenghi E, Carré M, Martin-Tanguy J (1995) Effects of inhibitors of polyamine biosynthesis and polyamines on strawberry microcutting growth and development. Plant Cell Tiss Org Cult 42:47-55 
Thorpe TA (1980) Organogenesis in vitro: structural, physiological, and biochemical aspects. In: Vasil IK (ed) Perspectives in plant cell and tissue culture. Int Rev Cytol, Suppl 11A, Academic Press, New York, pp 71-105

Van den Driessche R (1983) Rooting of Sitka spruce cuttings from hedges, and after chilling. Plant Soil 71:495-499. doi:10.1007/ BF02182691

Veierskov B (1988) Relations between carbohydrates and adventitious root formation. In: Davis TD, Haissig BE, Sankhla N (eds) Adventitious root formation in cuttings. Advanced plant science series, vol 2. Dioscorides Press, Portland, pp 11-28

Wang J, Pan R (2006) Effect of ethylene on adventitious root formation. In: Khan NA (ed) Ethylene action in plants. Springer, Berlin, pp 69-79

Wenger KF (1984) Forestry handbook, 2nd edn. Wiley, New York

Wiesman Z, Lavee S (1995) Enhancement of IBA stimulatory effect on rooting of olive cultivar stem cutting. Sci Hortic 65:189-198. doi:10.1016/0304-4238(95)00772-L
Wiesman Z, Riov J, Epstein E (1989) Paclobutrazol and ureaphosphate increase rooting and survival of peach "Maravilha" softwood cuttings. HortScience 24:908-909

Zavattieri A, Lima M, Sobral V, Oliveira P, Costa A (2009) Effects of carbon source, carbon concentration and culture conditions on in vitro rooting of Pinus pinea L. microshoots. Acta Hortic 812:173-180

Zel J, Gogala N, Camloh M (1988) Micropropagation of Pinus sylvestris. Plant Cell Tissue Organ Cult 14:169-175

Zhang Y, Wei Z, Xi M, Shi J (2006) Direct organogenesis and plantlet regeneration from mature zygotic embryos of masson pine (Pinus massoniana L.). Plant Cell Tissue Organ Cult 84: 119-123. doi:10.1007/s11240-005-9004-z 